Egyptian Journal of Rabbit Science, 29 (1): 23-43(2019)

\title{
GENETIC EVALUATION OF SOME DOE, LITTERAND LACTIONTRAITS OF NEW ZEALAND WHITE RABBITS
}

\author{
Amira S. El-Deghadi. \\ Animal Production Research Institute, Agriculture Research Center, \\ Ministry of Agriculture, Dokki, Cairo, Egypt.
}

Data collected on 765 litters produced from 261 does and 69 sires of New Zealand White for five consecutive years. The data of doe traits $(D B W=$ doe body weight, DPE = doe production efficiency), litter traits $(L S B=$ litter size at birth, $L S W=$ litter size at weaning, $L W 1, L W 2, L W 3$ and LW4 = litter weight at $1^{\text {st }}, 2^{\text {nd }}, 3^{\text {rd }}$ week and $4^{\text {th }}$ week of age respectively, litter gain traits ( $L G 1=$ litter gain from birth to $1^{\text {st }}$ week, $L G 2=$ litter gain from birth to $2^{\text {nd }}$ week, LG3= litter gain from birth to $3^{\text {rd }}$ week, LG4= litter gain from birth till to $4^{\text {th }}$ week of age resp.) and lactation traits $\left(M Y 1, M Y 2, M Y 3\right.$ and MY4) = milk yield during the $1^{\text {st }}$, $2^{\text {nd }}, 3^{\text {rd }}$ and $4^{\text {th }}$ week respectively, milk conversion ratio (MCR1, MCR2, MCR 3 and MCR4 = milk conversion ratio from kindling till $1^{\text {st }}, 2^{\text {nd }}, 3^{\text {rd }}$ and $4^{\text {th }}$ week respectively ( $g$ litter gain per $g$ of milk suckled during $1^{\text {st }}$, $2^{\text {nd }}, 3^{\text {rd }}$ and $4^{\text {th }}$ weeks respectively of lactation). Heritability for doe traits were low (0.05 for $D B W$ and 0.08 for DPE); $h^{2}$ were low ranged from 0.01 to 0.06 for litter size ( $L S B$ and $L S W$ ); from 0.07 to 0.20 for litter weights.

The trend was the same in the case of both litter gain and milk traits. The highest repeatability $R^{2}$ estimates $(0.74$ and 0.76$)$ were obtained for DBW and MCR4. $R^{2}$ estimates for other studied traits tended to be low to moderate in magnitude and ranged from 0.01 to 0.20 for litter traits and ranged from 0.14 to 0.40 for milk traits. The ranges of transmitting ability were 248.29 and 0.234 grams for DBW, DPE; ranged from 0.297 to 880.54 grams for litter traits, ranged from 0.383 .22 to 416.29 grams for milk yield, finally ranging from 0.584 to $5.06 \%$ for milk conversion ratio from kindling till $1^{\text {st }}, 2^{\text {nd }}, 3^{\text {rd }}$ and $4^{\text {th }}$ week respectively. The percentages positive transmitting ability estimates were 48.41 and $47.52 \%$ for doe traits, ranged from 46.37 to $52.99 \%$ for litter traits and ranging from 33.63 to $46.50 \%$ for lactation traits. The ranges of transmitting abilities estimates for top $25 \%$ of animals were 121.28 and $0.117 \%$ for doe traits, ranged from 0.124 to $0.841 \%$ for litter traits. The rank correlation was negative, moderate and highly significant between DBW and DPE were generally positive, 
moderate and high for litter sizes and litter weights traits and ranged from 0.22 to 0.94. The same trend between litter traits and litter gains except between LSB and LG2 and LSB and LG3 were 0.09 and -0.17 resp. The values of rank correlation of lactation traits were negative, positive, moderate or high and characterized by highly significant. Generally the values of genetic trend were varied and increased by increasing years for all traits under studies; the higher values were for LSW, LW4, LG4, MY1, MY2 and MRC4.

Conclusively, although the heritability of doe, litter and lactation were low orland moderate, it appear to be within the range of values notified in the literature; and suggest that genetic selection must be done considering a higher number of related animals and more accurate statistical methods of selection for doe, litter and lactation in rabbits. So genetic evaluation and continuous selection for economic traits is very useful to increase its productive and reproductive performance. This will help the rabbit's producers' to increase their production and profits.

Key words: Rabbits, heritability, repeatability, transmitting ability, rank correlation and genetic trend,

Doe and litter traits are the most important characters for prolificacy of the rabbit doe and survival rate of litters during suckling period. Early litter growth and mortality rate in rabbits depend in part on the intrinsic ability of the doe to provide adequate milking ability with better maternal environment(El-Maghawry et al., 1993; El-Sayiad, 1994; Khalil, 1994; Nasr, 1994 and Khalil et al., 2004; Youssef et al., 2008 and Iraqi, 2008). So the milk yield of the doe is the major pronounced postnatal maternal component influencing pre-weaning litter growth in terms of litter size and litter weight(Nasr 1994 and El-Raffa et al., 1997). Development and evaluation of sound breeding programs depend upon accurate knowledge of both environmental and genetic parameters (El-Raffa, 2005).Khalil et al.(1987) concluded that the potential for genetic improvement is largely depended on the heritability of the trait measured and its relationship with other traits of economic importance. El-Amin et al., 2011, reported that heritability, which is a function of variance components, provides information about the genetic nature of a trait and is needed for genetic evaluation and selection strategies. Estimates of heritability and repeatability for doe, litter and lactation traits were mostly low and have a broad range among reports, as reviewed by Khalil et al.,(1986). It could be improved by selection and/or culling strategies (Afifi 
et al., 1989;Lukefahr and Hamilton, 1997). A breeding gain in a rabbit flock depends on the breeding value (BV) of the selected individuals. The breeding value of an individual concerns the genetic merit that an individual transmit to its offspring (Chapman, 1985).The accuracy of the individuals breeding value estimation becomes more precise together with extending the information not only by their own performance test, but also of both the full and half sibs as well as of the ancestors (Wezyk and Szwaczkowski, 1993).

Therefore, the main objective of this study was, to evaluate genetically doe, litter and lactation traits in New Zealand White rabbits through prediction of the transmitting ability of individuals using single trait animal models, obtaining the genetic trend, and determination of rank correlations among the studied traits.

\section{MATERIALS AND METHODS}

\section{Animals and data:}

Data collected on 765 litters produced from 261 does and 69 sires for five consecutive years, was carried out at the Rabbitry of Faculty of Agriculture at Moshtohor, Benha University, on New Zealand White (NZW) rabbit breed. The data of doe traits $(\mathrm{DBW}=$ doe body weight, $\mathrm{DPE}=$ doe production efficiency computed as litter weaning weight divided to doe body weight at parturition), litter traits (LSB = litter size at birth, LSW = litter size at weaning, litter weights (LW1, LW2, LW3 and LW4 $=$ litter weight at $1^{\text {st }}$, $2^{\text {nd }}, 3^{\text {rd }}$ week and $4^{\text {th }}$ week respectively) and gain traits(LG1= litter gain from birth to $1^{\text {st }}$ week, $L G 2=$ litter gain from birth to $2^{\text {nd }}$ week, LG3= litter gain from birth to $3^{\text {rd }}$ week, $\mathrm{LG} 4=$ litter gain from birth to $4^{\text {th }}$ week resp.). Also lactation traits $(M Y 1, M Y 2, M Y 3$ and MY4 $)=$ milk yield during the $1^{\text {st }}, 2^{\text {nd }}$, $3^{\text {rd }}$ and $4^{\text {th }}$ week respectively; and milk conversion ratio (MCR1, MCR2, MCR3 and MCR $4=$ milk conversion ratio from kindling till $1^{\text {st }}, 2^{\text {nd }}, 3^{\text {rd }}$ and $4^{\text {th }}$ week respectively computed as litter gain per g of milk suckled during $1^{\text {st }}$, $2^{\text {nd }}, 3^{\text {rd }}$ and $4^{\text {th }}$ weeks respectively of lactation). Mating, according to the breeding plan, a buck was assigned at random for every 3-4 does for mating with a restriction of avoiding full sib, half sib and parent-offspring mating. Each buck was given the chance to produce all his litters from the its females all over the period of the study. Does were palpated 10 days later.

Therefore, the mating design produced several progeny for each successful sire-dam combination. Data were analyzed using repeatability single-trait animal model of doe, litter and lactation traits using MTDFREML programs of Boldman et al. (1995). Variances obtained by REML method of VARCOMP procedure (SAS, 2003) were used as starting 
(guessed) values for the estimation of variance components. Analyses were done according to the general model:

$$
\mathrm{y}=\mathrm{Xb}+\mathrm{Z}_{1} \mathrm{a}+\mathrm{Z}_{2} \mathrm{p}+\mathrm{e} \text {. }
$$

Where, $y=$ Vector of observation, $X=$ Incidence matrix of fixed effects; $b=$ Vector of fixed effects including season (3 levels) and parity (5 levels); $Z_{1}$ and $\mathrm{Z}_{2}=$ Incidence matrices corresponding to random effects of additive (a) and permanent environment ( $\mathrm{p}_{\mathrm{e}}$, doe effect), respectively. Heritability were computed as additive direct $\left(h^{2}{ }_{a}=\sigma_{a}^{2} l \sigma_{p}^{2}\right)$ where $\sigma^{2} a$ and $\sigma^{2} p$ are the variances due to effects of additive genetic and phenotypic, respectively, and Repeatability which $R^{2}=\left(\sigma_{a}^{2}+\sigma_{p e}^{2}\right) / \sigma_{p}^{2}$. Repeatability was expressed as the ratio of variances by summing additive genetic and permanent environmental to total phenotypic variance.

\section{Rank correlation:}

Spearman rank correlations among ranks of predicted transmitting ability estimates between the studied traits were computed by SAS program(SAS,2003).

\section{Genetic trend:}

Genetic trends estimated as a regression coefficient of breeding values on year of birth, which present generation number using SAS program(SAS,2003).

\section{RESULTS AND DISCUSSION}

\section{Means:}

Table 1 show the actual means, standard deviations, ranges in variation and coefficient of variability of doe, litter and lactation traits to characterize the New Zealand White rabbits. Means of the doe, litter traits are within the ranges which were observed by many researchers (Khalil et al., 1995; Afifi et al., 1998; El-Maghawry 1999; Khalil and Afifi 2000; Nofal et al., 2002; Hassan, 2005b; Ramadan 2005; Youssef et al., 2008; Iraqi, 2008; and Okoro et al., 2012). These results may indicate good maternal ability and higher reproductive performance of doe. Coefficients of variability ranged from 9.15 to $41.14 \%$ for doe and litter traits. These trends are similar to that findings by (El-Maghawary, 1999; Hassan, 2005b; Ramadan 2005; Youssef et al.,2008 and Iraqi, 2008andOkoroet al., 2012). This may be due to many effects such as genetic make-up of the does, non-genetic effects (yearseason, parity and management of the herd). In this study means of litter traits are higher than those reported by Fayeye and Ayorinde (2016) who 
Table 1. Actual means, standard deviations (SD), coefficients of variation $(\mathrm{CV} \%)$ and Min. and Max. ranges in variation for doe, litter and lactation traits in New Zealand White rabbits.

\begin{tabular}{|l|c|c|c|c|c|}
\hline Traits +: & Mean & SD & CV\% & Min. & Max. \\
\hline Doe traits: & & & & & \\
DBW & 3766.3 & 344.59 & 9.15 & 2650 & 5135 \\
DPE & 0.78 & 0.33 & 41.96 & 0.20 & 2.2 \\
Litter traits: & & & & & \\
LSB, young & 6.8 & 1.99 & 29.38 & 2 & 13 \\
LSW, young & 5.0 & 2.00 & 40.22 & 2 & 11 \\
LWB, g & 428.9 & 125.73 & 29.31 & 100 & 800 \\
LW1, g & 947.3 & 333.44 & 35.20 & 250 & 2500 \\
LW2, g & 1538.3 & 568.70 & 36.97 & 420 & 3655 \\
LW3, g & 2142.0 & 837.98 & 39.12 & 490 & 4900 \\
LW4, g & 2902.0 & 1193.77 & 41.14 & 550 & 6930 \\
LG1, g & 518.3 & 293.00 & 56.53 & 40 & 1850 \\
LG2, g & 1109.4 & 525.68 & 47.38 & 70 & 3125 \\
LG3, g & 1713.1 & 795.26 & 46.42 & 110 & 4320 \\
LG4, g & 2473.1 & 1150.1 & 46.50 & 170 & 6400 \\
Lactation traits: & & & & & \\
MY1, g & 831.6 & 300.08 & 36.09 & 210 & 2555 \\
MY2, g & 970.0 & 354.18 & 36.52 & 105 & 3390 \\
MY3, g & 1082.5 & 430.67 & 39.78 & 105 & 2710 \\
MY4, g & 514.4 & 341.50 & 66.39 & 70 & 595 \\
MCR1 & 0.66 & 0.38 & 57.47 & 0.3 & 2.46 \\
MCR2 & 1.23 & 0.63 & 51.07 & 0.15 & 4.14 \\
MCR3 & 1.77 & 1.09 & 61.44 & 0.27 & 13.82 \\
MCR4 & 6.79 & 7.26 & 107.02 & 0.67 & 73.71 \\
\hline
\end{tabular}

+DBW $=$ doe body weight, DPE $=$ doe production efficiency, LSB $=$ Litter size at birth, LSW $=$ Litter size at weaning, LW1, LW2, LW3 and LW4 $=$ Litter weight at $1^{\text {st }}, 2^{\text {nd }}, 3^{\text {rd }}$ week and $4^{\text {th }}$ week respectively. LG1 = Litter gain from birth to $1^{\text {st }}$ week, LG2= Litter gain from birth to $2^{\text {nd }}$ week, LG3 = Litter gain from birth to $3^{\text {rd }}$ week, LG4= Litter gain from birth to $4^{\text {th }}$ week, MY1, MY2, MY3 and MY4 = Milk yield during the $1^{\text {st }}, 2^{\text {nd }}, 3^{\text {rd }}$ and $4^{\text {th }}$ week respectively.MCR1, MCR2, MCR3 and MCR4 = Milk conversion ratio from kindling till $1^{\text {st }}, 2^{\text {nd }}, 3^{\text {rd }}$ and $4^{\text {th }}$ week respectively (g litter gain per $g$ of milk suckled during $1^{\text {st }}, 2^{\text {nd }}, 3^{\text {rd }}$ and $4^{\text {th }}$ weeks respectively of lactation).

found that mean litter size at birth, litter birth weights, litter size at weaning and litter weaning weights were $4.50 \pm 1.50,198.00 \pm 68.00,3.57 \pm 1.64$ and1154.57 \pm 57.00 , respectively.

Means of milk yield and milk efficiency were increased gradually from the $1^{\text {st }}$ week up to the $3^{\text {rd }}$ week, and then decline in the $4^{\text {th }}$ week. These trends 
are similar to the findings which were observed by (El-Maghawary, 1999; Hassan, 2005a\&b; Ramadan 2005; Youssef et al.,2008 and Iraqi, 2008). This may be due to decrease in milk amount produced by the doe during late pregnancy as a result of suckling or dry ration consumed by the young (ElMaghawry et al., 1993).

Coefficients of variability for milk yield and milk efficiency through the intervals of lactation were high and varied from $36.09 \%$ to $107.02 \%$. These estimates are in agreement with the results of(ElMaghawary, 1999;Hassan, 2005a\&b; Ramadan 2005; Youssef et al., 2008 and Iraqi, 2008).

\section{Heritability:}

Table 2 showed estimates of heritability, permanent, residual effects, and repeatability (t) estimates for doe, litter and lactation traits in New Zealand White rabbits. Heritability for doe traits were low and 0.05 for DBW and 0.08 for DPE. In this respect Lukefahr and Hamilton (1997) found that $\mathrm{h}^{2}$ was 0.07 for DPE and 0.53 for DBW when they used pooled data collected on purebreds of Californian and New Zealand White rabbits breeds. Iraqi (2008) found a very low heritability estimates for doe traits in NZW 0.001 for DBW and 0.09 for DPE. These low $\mathrm{h}^{2}$ estimates may be due to higher permanent environmental effects $(66 \%)$ on this trait. They added that estimate of $h^{2}$ for DPE indicated that this trait could be used as selection criteria to improve doe traits in NZW rabbit in their population.

Estimates of $\mathrm{h}^{2}$ for litter traits were low or/and moderate and ranged from 0.01 to 0.06 for litter size traits, from 0.07 to 0.20 for litter weights and from 0.10 to 0.15 for litter gain traits. Small estimates of $h^{2}$ for these traits also may be due to higher non-additive genetic effects over additive effects for all doe and other litter traits. These results are within the ranges which were observed by many researchers (Baselga et al.,1992; Ferraz et al., 1992; Panella et al., 1992; Khalil, 1994; Ayyat et al., 1995; Lukefahr et al.,1996; Lukefahr and Hamilton; 1997;El- Maghawry, 1999; Baselga and Garcia; 2002; Nofal et al., 2002; Hassan, 2005b; Ramadan 2005; Youssef et al., 2008 and Saef et al., 2008). El-deghadi (2005) reported that although low estimates of $h^{2}$ for litter traits and the relative importance of additive genetic effects which can use the crossbreeding schemes to improve these traits may be realized by crossbreeding. Okoro et al.(2012) found that estimates of sire heritability for litter weight at birth, at weaning, 21days, 42days and 56 dayswere $0.34 \pm 0.41,0.79 \pm 0.632,0.91 \pm 1.20$ and $0.62 \pm 0.542$ respectively. These estimates cleared arrange of moderate to high heritability and 
Table 2.Estimates of heritability $\left(\mathrm{h}^{2}\right)$, permanent $\left(\mathrm{P}^{2}\right)$, error effects $\left(\mathrm{e}^{2}\right)$, and repeatability $\left(\mathrm{R}^{2}\right)$ estimates for doe, litter and lactation traits in NZW rabbits.

\begin{tabular}{|l|c|c|c|c|}
\hline Traits+: & $\mathbf{h}^{2} \pm \mathbf{S E}$ & $\mathbf{P}^{2} \pm \mathbf{S E}$ & $\mathbf{e}^{2} \pm \mathbf{S E}$ & $\mathbf{R}^{2}$ \\
\hline Doe traits: & & & & \\
DBW & $0.05 \pm 0.03$ & $0.69 \pm 0.02$ & $0.26 \pm 0.31$ & 0.74 \\
DPE & $0.08 \pm 0.04$ & $0.014 \pm 0.25$ & $0.90 \pm 0.25$ & 0.09 \\
Litter traits: & & & & \\
LSB, young & $0.01 \pm 0.03$ & $0.002 \pm 0.26$ & $0.99 \pm 0.26$ & 0.01 \\
LSW, young & $0.06 \pm 0.04$ & $0.001 \pm 0.25$ & $094 \pm 0.25$ & 0.06 \\
LWB, g & $0.07 \pm 0.04$ & $0.078 \pm 0.28$ & $0.92 \pm 0.28$ & 0.15 \\
LW1, g & $0.20 \pm 0.04$ & $0.001 \pm 0.05$ & $0.80 \pm 0.02$ & 0.20 \\
LW2, g & $0.11 \pm 0.01$ & $0.016 \pm 0.02$ & $0.87 \pm 0.02$ & 0.13 \\
LW3, g & $0.09 \pm 0.01$ & $0.08 \pm 0.01$ & $0.83 \pm 0.02$ & 0.17 \\
LW4, g & $0.08 \pm 0.01$ & $0.037 \pm 0.01$ & $0.91 \pm 0.02$ & 0.12 \\
LG1, g & $0.12 \pm 0.04$ & $0.001 \pm 0.06$ & $0.88 \pm 0.05$ & 0.12 \\
LG2, g & $0.13 \pm 0.02$ & $0.065 \pm 0.01$ & $0.81 \pm 0.02$ & 0.20 \\
LG3, g & $0.10 \pm 0.01$ & $0.079 \pm 0.01$ & $0.82 \pm 0.02$ & 0.18 \\
LG4, g & $0.15 \pm 0.01$ & $0.001 \pm 0.01$ & $0.76 \pm 0.02$ & 0.15 \\
Lactation traits: & & & & \\
MY1, g & $0.11 \pm 0.04$ & $0.16 \pm 0.08$ & $0.74 \pm 0.04$ & 0.27 \\
MY2, g & $0.15 \pm 0.04$ & $0.11 \pm 0.01$ & $0.75 \pm 0.04$ & 0.26 \\
MY3, g & $0.14 \pm 0.01$ & $0.003 \pm 0.01$ & $0.86 \pm 0.02$ & 0.14 \\
MY4, g & $0.07 \pm 0.04$ & $0.11 \pm 0.05$ & $0.82 \pm 0.04$ & 0.18 \\
MCR1 & $0.08 \pm 0.04$ & $0.025 \pm 0.23$ & $0.89 \pm 0.23$ & 0.11 \\
MCR2 & $0.10 \pm 0.04$ & $0.20 \pm 0.21$ & $0.70 \pm 0.21$ & 0.30 \\
MCR3 & $0.16 \pm 0.04$ & $0.24 \pm 0.22$ & $0.60 \pm 0.22$ & 0.40 \\
MCR4 & $0.07 \pm 0.09$ & $0.69 \pm 0.17$ & $0.25 \pm 0.16$ & 0.76 \\
\hline
\end{tabular}

+ Traits as defined in Table 1 .

suggested that selection of this non-descript population of rabbits for litter weight at weaning, litter weight at 42 days and litter weight at 56 days could be efficient in improving these traits in the population. Hassan et al., (2015a) found that heritability of the considered doe traits were relatively low being $0.17,0.04$ and 0.11 for litter weights at birth; 21 days and weaning; resp., and they suggested that, it can be concluded that family or within family selection could be more effective and valuable than individual selection to improve these traits of APRI does of rabbits under the Egyptian North-Delta climatic conditions. Hassan et al., (2015b) found that heritability of the considered doe traits were 
relatively low being $0.14,0.14$ and 0.13 for litter gains (litter gain from birth up to 21 day, litter gain from birth up to weaning and litter gain from 21 day up to weaning) resp. Fayeye and Ayorinde, (2016), found that heritability for litter size at birth, litter birth weight, litter size at weaning and litter weaning weight were $0.60 \pm 0.56,0.96 \pm 0.42,0.84 \pm 0.76$ and $0.92 \pm 0.40$, respectively and the estimates of heritability suggest strong contribution of additive genes in the expression of all the litter traits. Thus our estimates of $h^{2}$ are agree with the Egyptian researchers with the same conditions.

Estimates of $\mathrm{h}^{2}$ for milk yield were low or / and moderate and ranged 0.11, $0.15,0.14$ and 0.07 during $1^{\text {st }}, 2^{\text {nd }}, 3^{\text {rd }}$ and $4^{\text {th }}$ week respectively. Also Estimates of $\mathrm{h}^{2}$ for milk efficiency during different weeks of lactation were low or moderate and ranged 0.08, 0.10, 0.16 and 0.07 that agree with Hassan, (2005b) reported that estimates of $h^{2}$ for milk yield were relatively very low.

Added that heritability estimates in BB rabbits were to some extent lower than those of NZW that ranged from 0.001 to 0.03031 and from 0.001 to 0.07298 in NZW and Baladi Black rabbits, respectively. Iraqi and Youssef (2006) reported that estimates of $\mathrm{h}^{2}$ for milk production traits in NZW were low and ranged from 0.001 for total milk yield during $1^{\text {st }}$ week to 0.05 for total milk yield during $3^{\text {rd }}$ week. Iraqi, 2008 reported that estimates of $\mathrm{h}^{2}$ for milk production traits were small 0.01 for litter milk efficiency from 1 to 21 day and ranged from 0.08 to 0.11 for milk coefficient and from 0.0 to 0.11 for milk yield traits and also milk coefficients during different intervals which were, generally, higher than the other milk production traits. Youssef et al.,(2008) reported that heritability estimates for milk production traits in NZW and Baladi Black rabbits were low and ranged from 0.01 to 0.12.Benjanin Gomez-Ramos et al., (2010) reported that the heritability of milk production was low and they suggested that genetic selection must be done considering a higher number of related animals and more accurate statistical methods of selection for improving milk yield in rabbits.

\section{Permanent environmental effects:}

Permanent environmental effects were moderate or high and ranged from 0.014 to 0.69 for doe trait. The estimates of $\mathrm{P}^{2}$ were low and moderate, which ranging from 0.001 to 0.08 for litter traits and ranging 0.003 to 0.25 for milk traits, except for MRC4 which have the highest estimates (0.69). Similar results were observed by (Ahmed, 1997;El-Maghawry,1997; Lukefahr and Hamilton, 1997; Youssef et al., 2003; Youssefet al., 2008 and Iraqi, 2008). There are many traits have higher effects of permanent than additive effects .Moura et al., (1991) suggested that in general, the small values $\mathrm{P}^{2}$ may be attributed partially to the large temporary environmental variation (included sanitary and 
managerial conditions etc...), which could not be considered in statistical models, Lukefahr and Hamilton (1997) suggested that adding the permanent source of variation were important for doe body weight and also for litter weaning weight. Also, Iraqi, (2008) suggested that the permanent environmental effects should be considered when studying the doe, litter and milk production traits. Hassan et al., (2015a) found that permanent litter effect were low being 0.2, 0.002 and 0.008 for litter weight at birth, 21 days and weaning, resp. Also Hassan et al., (2015b) found that permanent considered doe traits were relatively low being $0.14,0.14$ and 0.13 for litter gains (litter gain from birth up to 21 day, litter gain from birth up to weaning and litter gain from 21 day up to weaning), respectively.

\section{Error proportion $e^{2}$ :}

Error proportions $\mathbf{e}^{2}$ ranged from moderate to high that were 0.25 to 0.94 for all doe, litter and milk traits. Similar results were observed by (Youssef et al.,2003; Youssef et al., 2008 Iraqi, 2008 and Hassan et al., 2015a).

\section{Repeatability:}

Repeatability estimated for doe, litter and milk traits are presented in Table 2 . The highest repeatability estimates $(0.74$ and 0.76$)$ were obtained for DBW and MCR4. $\mathrm{R}^{2}$ estimates for other studied traits tended to be ranged from low to moderate in magnitude that ranging from 0.01 to 0.20 for litter traits and from 0.14 to 0.40 for milk traits. These trends are within the ranges of many researchers (Khalil, 1994; Lukefahr and Hamilton,1997; Iraqi and Youssef, 2006; Youssef et al., 2008 and Iraqi, 2008). However Okoro et al., (2012) found that repeatability for litter weight at birth, at weaning i.e. 21day, 42day and 56day were $0.034 \pm 0.243, \quad-0.130 \pm 0.197, \quad 0.003 \pm 0.236$ and $0.008 \pm 0.238$ respectively.

These estimates indicate the repeatability of these traits being very low, and suggested that the likelihood to repeat these records is low. Fayeye and Ayorinde, (2016) found that repeatability for litter size at birth, litter birth weight, litter size at weaning and litter weaning weight were low and ranged $0.23 \pm 0.13,0.31 \pm 0.07,0.23 \pm 0.04$ and $0.31 \pm 0.21$, respectively. Zaharaddeen and. Kabir (2018) reported that the high estimates of repeatability for traits of GL, LBW, LSW and LWW indicates certainty of repeating these traits in subsequent generation, however assessment of several parities before selecting parents for these studied traits is necessary for effectiveness since LSB and NSR showed moderate repeatability estimates from the same population. More so, the principal component analysis presents a more reliable approach in predicting desired characteristics compared to the use of original measured traits as 
predictors because of erroneous inferences from multicollinearity of interdependent explanatory variables. Thus, the components could be used as factor scores for predicting litter sizes and weights, and gestation lengths in domestic rabbits.

\section{Transmitting abilities:}

Animal transmitting ability, Minimum (Min.), Maximum (Max.), number and percentages of the higher $25 \%$ estimates for doe, litter and lactation traits are presented in Table 3.The ranges of transmitting ability were 248.29 grams and 0.234grams for DBW, DPE, ranging from 0.297 bunnies to 880.54 grams for litter traits, ranging from 0.383 grams to 416 grams for milk yield and ranging from 0.361 to 5.06 for milk conversion ratio during period studied. ElRaffa, (2000) found that transmitting ability estimates ranged from -0.32 to 0.36 for litter size at birth and from -0.24 to 0.24 for litter size at weaning. Hassan et al., (2015) found that transmitting ability estimates ranged from -0.32 to 0.36 for litter size at birth and from -0.24 to 0.24 for litter size at weaning.

These values for range of transmitting ability for litter size at birth were higher than this obtained in this study, and lower range of transmitting ability for litter size at weaning compared with the range presented in the current study. Hanaa et al.,(2014) reported that the ranges of transmitting ability for all animals estimated for weaning weight were 512 grams whereas, were 0.22 and 1.80 for litter size at birth and litter size at weaning and, these values are within range obtained in this study. They suggested that these variations can introduce the possibility of making the correct culling decision and selecting the best rabbits from those having positive estimates of transmitting ability for growth and/ or litter size traits. Hassan et al.,(2015) found that the ranges of the APRI does' transmitting ability were $0.67 \pm 0.19,0.340 \pm 0.13$ and $0.10 \pm 0.12 \mathrm{~g}$ for litter gain from birth up to 21 days, litter gain from birth up to weaning and litter gain 21 days up to weaning. They added the ranges for the same previous traits were $0.47 \pm 0.22,0.24 \pm 0.15$ and $0.07 \pm 0.14 \mathrm{~g}$, as for APRI dams' data transmitting ability.

The percentages positive transmitting ability estimates were 48.41 and 47.52\%fordoe traits, that ranging from 46.37 to 52.99 for litter traits and ranging from 33.63 to 46.50 for lactation traits. Our results are similar to the results founded by (Hanaa et al., 2014 and Hassan et al., 2015b), and these results are high enough to allow for genetic improvement bearing in mind that about $25 \%$ will be selected as a parent for replacement each year season (Hanaa et al., 2014).The ranges of transmitting abilities estimates for top $25 \%$ of animals were 121.28 and 0.117 for doe traits, ranging from 0.124 to 
Table 3. Animal transmitting ability, minimum (Min.), maximum (Max.), number and percentages of the positive records $(+)$ as well as the minimum and range of the higher $25 \%$ estimates for doe, litter and lactation traits in NZW rabbits.

\begin{tabular}{|l|c|c|c|c|c|c|c|}
\hline Traits: & Min. & Max. & Range & $\begin{array}{c}+ \\
\text { Records }\end{array}$ & $\begin{array}{c}\text { \% } \\
\text { + Records }\end{array}$ & \multicolumn{2}{c|}{$\begin{array}{c}\text { Higher 25\% } \\
\text { Min. }\end{array}$} \\
\hline $\begin{array}{l}\text { Doe traits: } \\
\text { DBW }\end{array}$ & -111.91 & 136.38 & 248.29 & 380 & 48.41 & 15.09 & 121.28 \\
\hline DPE & -0.101 & 0.133 & 0.234 & 373 & 47.52 & 0.160 & 0.117 \\
\hline $\begin{array}{l}\text { Litter traits: } \\
\text { LSB, young }\end{array}$ & -0.157 & 0.140 & 0.297 & 403 & 51.33 & 0.016 & 0.124 \\
\hline LSW, young & -0.553 & 0.903 & 1.46 & 380 & 48.41 & 0.062 & 0.841 \\
\hline LWB, g & -40.72 & 44.47 & 85.20 & 415 & 52.87 & 6.32 & 38.15 \\
\hline LW1, g & -212.83 & 380.27 & 593.10 & 361 & 45.99 & 37.59 & 342.68 \\
\hline LW2, g & -237.90 & 321.78 & 559.68 & 404 & 51.46 & 38.40 & 283.38 \\
\hline LW3, g & -300.12 & 366.75 & 666.87 & 413 & 52.61 & 46.88 & 319.87 \\
\hline LW4, g & -344.40 & 483.80 & 828.20 & 416 & 52.99 & 59.91 & 423.88 \\
\hline LG1, g & -217.68 & 531.47 & 749.15 & 364 & 46.37 & 50.24 & 481.24 \\
\hline LG2, g & -220.67 & 342.97 & 563.00 & 404 & 51.46 & 0.514 & 342.46 \\
\hline LG3, g & -265.82 & 369.566 & 635.38 & 413 & 52.61 & 42.14 & 327.42 \\
\hline LG4, g & -360.75 & 519.79 & 880.54 & 413 & 52.61 & 59.74 & 460.06 \\
\hline Lactation traits: & & \multicolumn{7}{|c|}{} & & & & & \\
\hline MY1, g & -98.55 & 242.75 & 341.29 & 365 & 46.50 & 17.61 & 225.13 \\
\hline MY2, g & -158.99 & 247.55 & 406.54 & 338 & 43.06 & 30.48 & 217.07 \\
\hline MY3, g & -165.83 & 251.14 & 416.98 & 364 & 46.37 & 27.89 & 223.26 \\
\hline MY4, g & -74.24 & 308.98 & 383.22 & 360 & 45.86 & 11.99 & 296.99 \\
\hline MCR1 & -0.107 & 0.254 & 0.361 & 354 & 45.10 & 0.020 & 0.234 \\
\hline MCR2 & -0.198 & 0.386 & 0.584 & 338 & 43.06 & 0.032 & 0.354 \\
\hline MCR3 & -0.446 & 1.64 & 2.09 & 333 & 42.42 & 0.058 & 1.59 \\
\hline MCR4 & -0.948 & 4.12 & 5.06 & 264 & 33.63 & 0.047 & 4.06 \\
\hline
\end{tabular}

+ Traits as defined in Table 1 .

0.841 for litter traits so litter size at weaning (0.841) the best trait to use criteria for improving the reproduction performance, these results for the same trait are in agreement with Hanaa et al.,(2014), ranging from 217.07 to 296.99 for milk yield during different weeks and ranging from 0.234 to 4.06 for milk conversion ratio during studied periods. These results may lead to a general conclusion that if a good selection plan will be adopted positive progress will achieved (Hanaa et al., 2014). 


\section{Rank correlations:}

Rank correlations and their significance among transmitting ability estimates for doe, litter and lactation traits are presented in Table 4. The rank correlation was negative, moderate and highly significant for DBW and DPE, were generally positive, moderate and high for litter sizes and litter weights traits and ranged from 0.22 to 0.94 .

The same trend between litter traits and litter gains, except between LSB and LG2 and LSB and LG3 were 0.09 and -0.17 resp. Hanaa et al., (2014) found that the rank correlation of LSW and LSB were moderate and suggested that litter size at weaning seems to be the most consistent trait that could be used as a selection criterion for improving reproductive performance in rabbits. The rank correlation were negative, positive, moderate or high and highly significant for lactation traits except for MY2 \& MRC1, MY3\&MRC2 and MY4 \& MRC3 which were low and not significant. From the previous results, the knowledge of these associations can be used in planning for more accurate selection programs taking into consideration the direction and size of the association between traits.

Table 4.Rank correlations among transmitting ability estimates for doe and litter traits in NZW rabbits

Traits as defined in Table 1.

\begin{tabular}{|c|c|c|c|c|c|c|c|c|c|}
\hline Traits: & DBW & LSW & LWB & LW2 & LW3 & LW4 & LG2 & LG3 & LG4 \\
\hline Doe traits: & & \multirow{12}{*}{$0.48^{* * * *}$} & \multirow{12}{*}{$\begin{array}{l}0.70^{\text {******* }} \\
0.46^{* * * *}\end{array}$} & \multirow{12}{*}{ 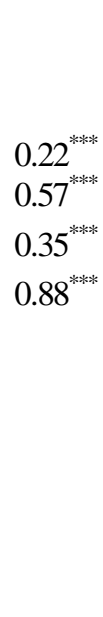 } & \multirow{12}{*}{$\begin{array}{l}0.25^{* * *} \\
0.59^{* * *} \\
0.37^{* * *} \\
0.78^{* * *} \\
0.94^{* * *}\end{array}$} & \multirow{12}{*}{$\begin{array}{l}0.24^{* * * *} \\
0.62^{* * * * *} \\
0.37^{* * *} \\
0.74^{* * * * *} \\
0.90^{* * * *} \\
0.94^{* * * *}\end{array}$} & \multirow{12}{*}{ 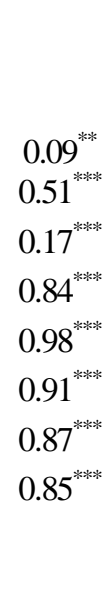 } & \multirow{12}{*}{$\begin{array}{l}-0.17^{* *} \\
0.55^{\text {**** }} \\
0.24^{\text {**** }} \\
0.76^{\text {**** }} \\
0.92^{\text {**** }} \\
0.99^{\text {**** }} \\
0.93^{\text {*** }} \\
0.73^{\text {**** }} \\
0.92^{\text {**** }}\end{array}$} & \multirow{12}{*}{$\begin{array}{l}0.16^{* * * *} \\
0.56^{* * * *} \\
0.25^{* * * *} \\
0.77^{* * * *} \\
0.93^{* * * *} \\
098^{* * * *} \\
0.92^{* * * *} \\
0.72^{* * * *} \\
0.94^{* * * *} \\
0.99^{* * * *}\end{array}$} \\
\hline & $-0.21^{* * * * *}$ & & & & & & & & \\
\hline $\begin{array}{l}\text { Litter traits: } \\
\text { LSB }\end{array}$ & & & & & & & & & \\
\hline LSW & & & & & & & & & \\
\hline LWB & & & & & & & & & \\
\hline LW1 & & & & & & & & & \\
\hline LW2 & & & & & & & & & \\
\hline LW3 & & & & & & & & & \\
\hline LW4 & & & & & & & & & \\
\hline LG1 & & & & & & & & & \\
\hline LG2 & & & & & & & & & \\
\hline LG3 & & & & & & & & & \\
\hline
\end{tabular}


Table 4 Cont.Rank correlations among transmitting ability estimates for lactation traits in NZW rabbits.

\begin{tabular}{|l|l|l|l|l|l|l|l|}
\hline Traits: & MY2 & MY3 & MY4 & MRC1 & MRC2 & MCR3 & MCR4 \\
\hline Lactation traits: & & & & & & & \\
MY1 & $0.56^{* * *}$ & $0.32^{* * *}$ & $0.33^{* * *}$ & $-0.25^{* * *}$ & $-0.12^{* * *}$ & $-0.13^{* * *}$ & $-0.11^{* * *}$ \\
MY2 & & $0.51^{* * *}$ & $0.32^{* * *}$ & $0.06^{\mathrm{ns}}$ & $-0.36^{* * *}$ & $-0.20^{* * * *}$ & $-0.06^{\mathrm{ns}}$ \\
MY3 & & & $0.42^{* * * *}$ & $0.24^{* * *}$ & $-0.05^{\mathrm{ns}}$ & $-0.39^{* * * *}$ & $-0.20^{* * *}$ \\
MY4 & & & & $0.10^{* * *}$ & $0.06^{\mathrm{ns}}$ & $-0.16^{* * *}$ & $-0.50^{* * *}$ \\
MRC1 & & & & & $0.61^{* * * *}$ & $0.34^{* * * *}$ & $0.20^{* * * *}$ \\
MRC2 & & & & & & $0.58^{* * *}$ & $0.23^{* * * *}$ \\
MRC3 & & & & & & & $0.39^{* * *}$ \\
MRC4 & & & & & & & \\
\hline
\end{tabular}

Traits as defined in Table 1.

\section{Genetic trend:}

Genetic trend estimates for doe, litter and lactation traits are presented in Figures 1, 2, 3, 4 and 5. The values of genetic trend were low, negative and positive for LSB, LSW and PDE in fig. 1 and the higher value was for LSW which increased with advanced of year. These results are in agreement with Hanaa et al., 2014, who reported that genetic trend for LSW significantly increased with the advantage of generation number. These may reflect the improving of the performance of $\mathrm{V}$ Line does through increasing their mothering abilities, to take more care of their kits during the suckling period, year by year. In other Figures 2, 3, 4 and 5, generally the values of genetic trend were low and moderate, negative and positive which increased by increasing the generation order for LW1, LW2, LW3, LW4,DBW, LG1, LG2, LG3 LG4 and lactation traits respectively; the higher values for LW4, LG4, MY1, MY2 and MRC4.

From results, the negative trend could be due to improvement in environmental conditions such as nutrient composition of diet and management. Szendroe et al., (1998). The changes in nutrient composition of the diet may have contributed to an improvement in breeding conditions during the formation of such breed. Ferraz et al., (1992) reported that average estimates of PBV were not regressed on year because the variation in changes from year to year might be due to some monitor effects such as changes in management or disease out breaks. Abou Khadiga et al., (2010) reported that the genetic trends were also estimated using mixed model methodology which were significant and comparable (34.2 and $32.5 \mathrm{~g}$ ) for the selected trait (litter weaning weight) in APRI and V lines, respectively 

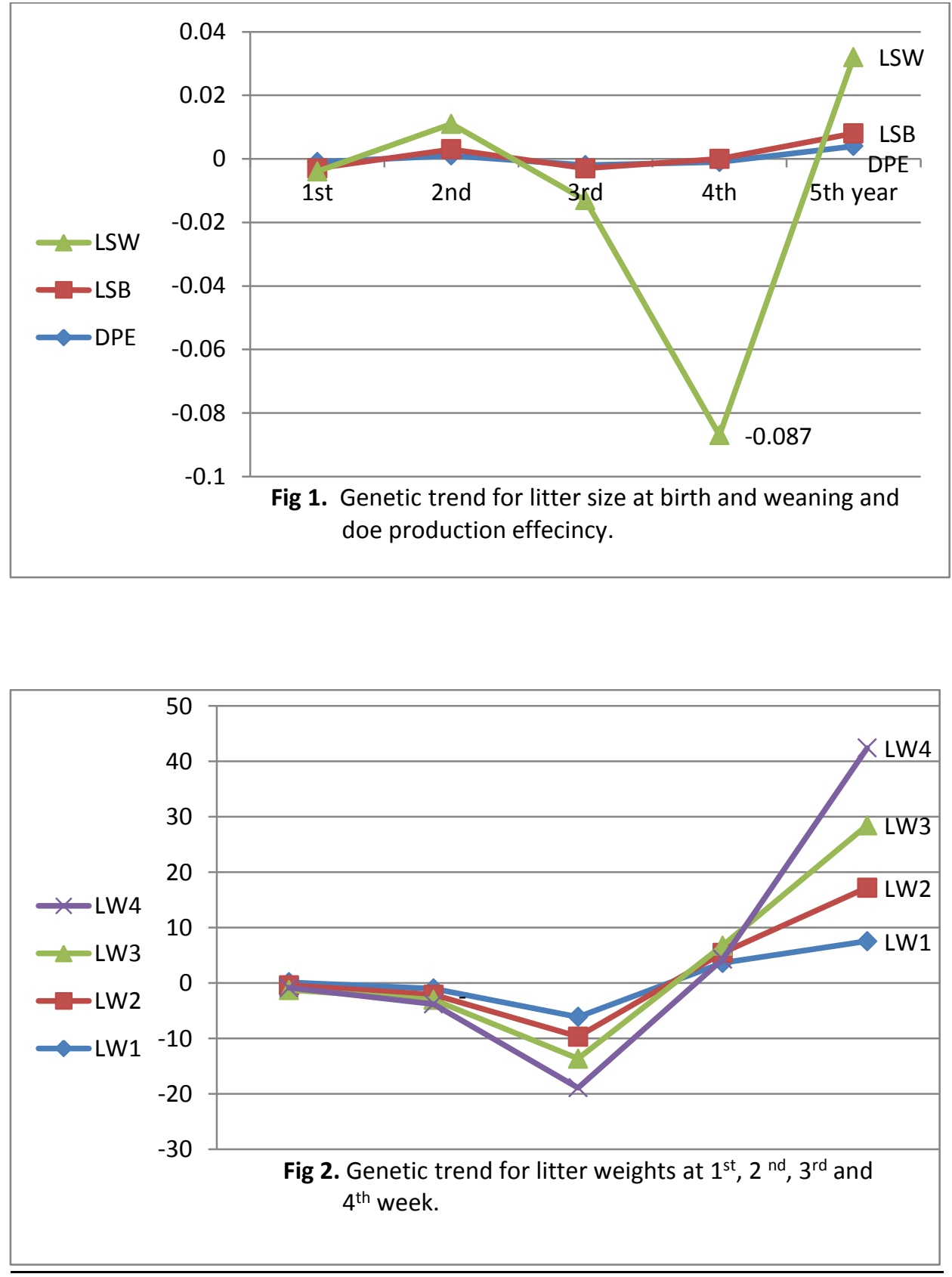

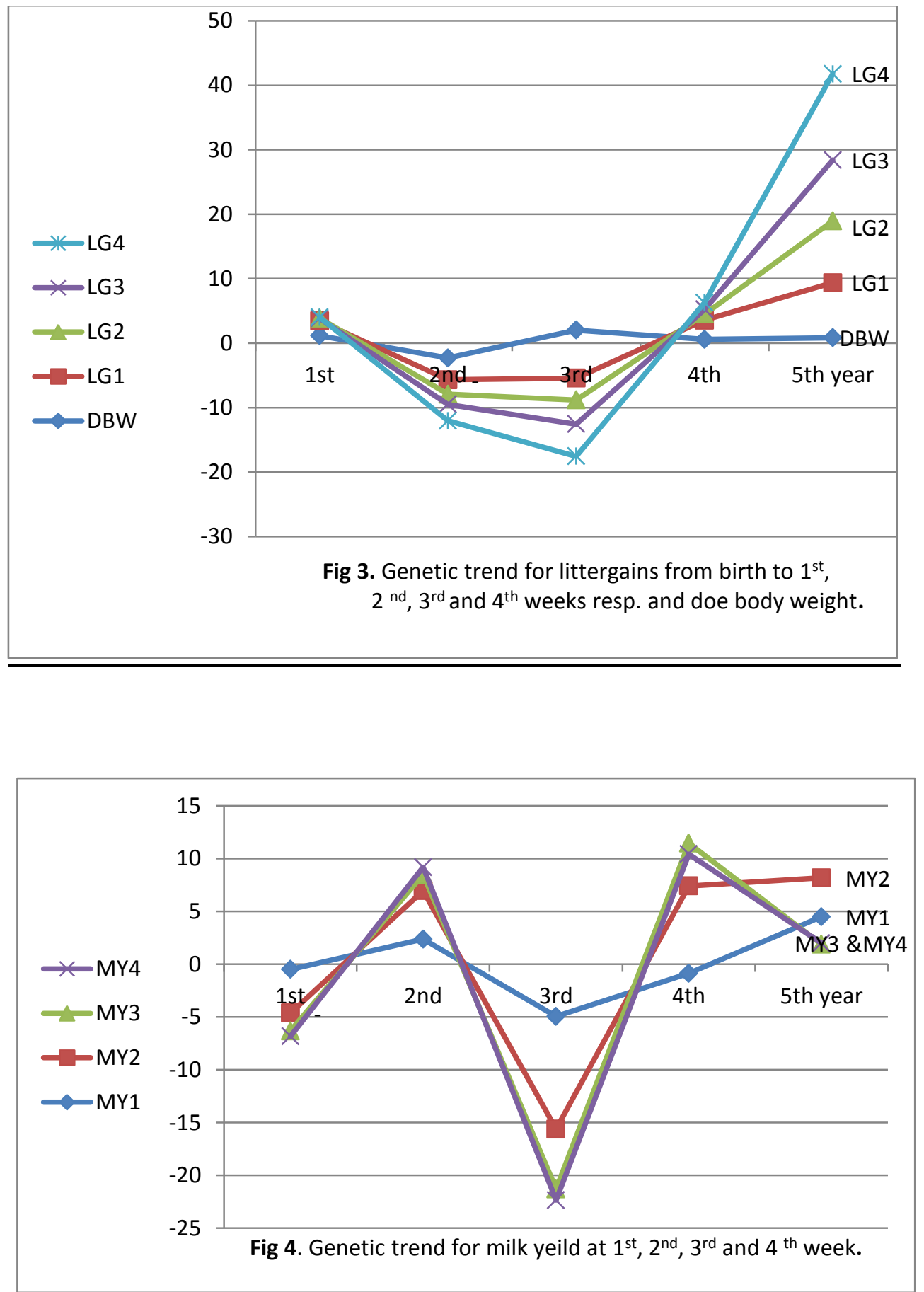


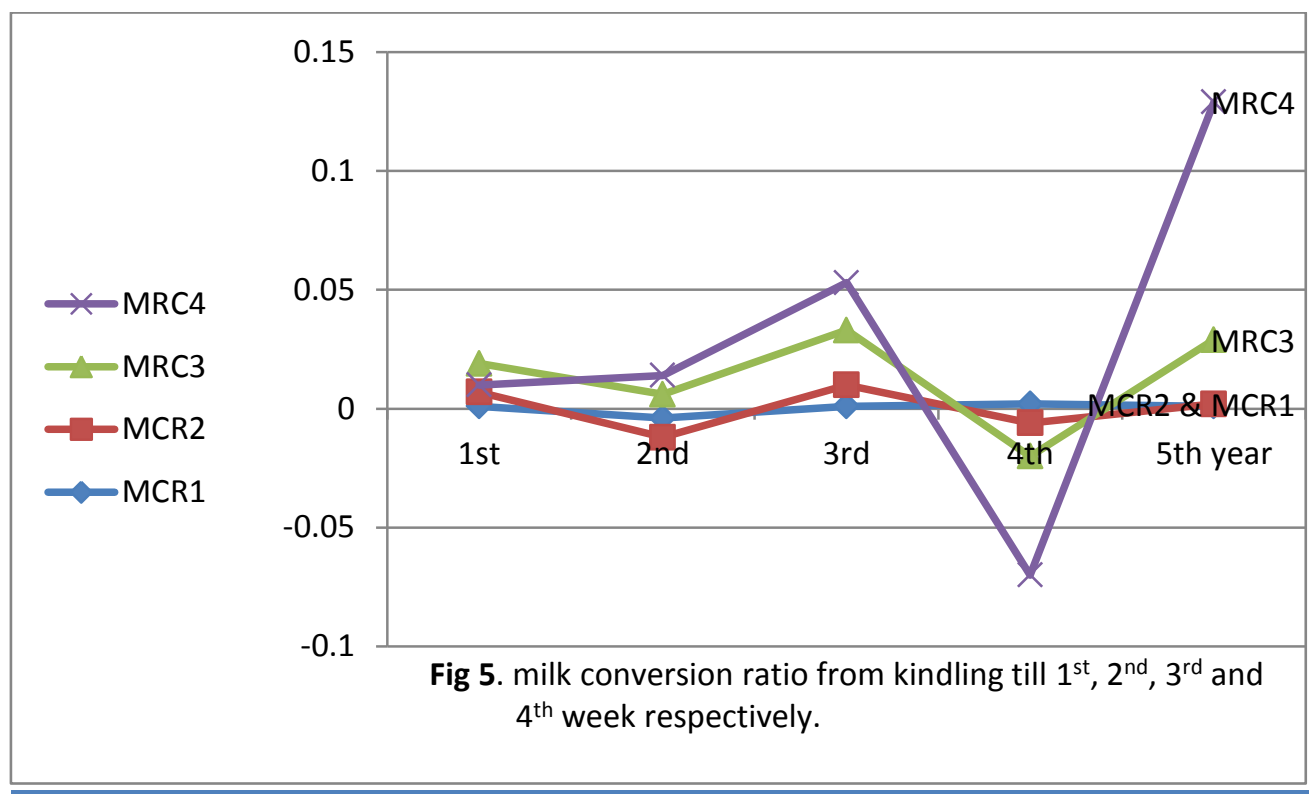

and differences in genetic trends throughout the experiments could be attributed to different populations and surrounding conditions, also environmental changes in LWW largely reflected seasonal variations in production. Year-season fluctuations were found in both lines. Generally, the dissimilarity among year-seasons in LWW could be attributed to the variation in climatic conditions.

\section{CONCLUSION:}

Although the heritability of doe, litter and lactation were low orland moderate, it appear to be within the range of values notified in the literature; and suggest that genetic selection must be done considering a higher number of related animals and more accurate statistical methods of selection for doe, litter and lactation in rabbits. So genetic evaluation and continuous selection for economic traits is very useful to increase its productive and reproductive performance. This will help the rabbit's producers' to increase their production and profits

\section{REFERENCES}

Afifi, E. E.A.; Abdel-Ghany, A.M.; Khattab, M.S. (1998). Litter weight and mean bunny weight per litter in two standard breeds of rabbits. $J$. Anim. Prod. , 35: 345-57 (Suppl). 
Abou Khadiga, G.; Youssef, Y. M. K.; Saleh, K.; Nofal, R. Y.; Baselga, M. (2010). Genetic trend in selection for litter weight in two maternal lines of Rabbits in Egypt. World Rabbit Sci.,18: 27 - 32.

Ahmed, E. G., (1997). Productive performance of different exotic strains of rabbits. Ph. D. Thesis, Faculty of Agriculture, Suez Canal University, Ismailia, Egypt.

Ayyat, M. S.; Marai, I. F. M.; El-Sayaid, G. H. A. (1995). Genetic and nongenetic factors affecting milk production and preweaning litter traits of New Zealand White does under Egyptian conditions. World Rabbit Science, 3: 119-124.

Baselga, M. and Garcia, M. L.(2002). Evaluating the response to selection in meat rabbit programmes. $3^{\text {rd }}$ Science Congress on Rabbit Production in hot climates, 8-11 Oct: 1-10-2002.

Baselga, M.; Gomez,.E.; Cifre, P. and Camacho, J. (1992). Genetic diversity of litter size traits between parities in rabbits. In: Proc. $5^{\text {th }}$ World Rabbit Congr., Oregon State Univ., Corvallis, July 1992,Volume A: 198-205.

BenjamínGómez-Ramos; José Herrera-Camacho;Ruy Ortiz-Rodríguez1; José Candelario; Segura-Correaand Carlos; Miguel Becerril-Pére. (2010). Heritability of milk yield in a population of rabbits under the conditions of the valley of mexico/heredabilidad de la produccion de leche en unapoblacion de conejasbajocondiciones de el valle de mexico .tropical and subtropical Agroecosystems, 12, 681-683.

BoldmanK. G., Kriese A., Van Vleck L D., Van Tassell C. P. and Kachman S. D.(1995). A manual for use of MTDFREML.A set of programs to obtain estimates of variances and covariances [DRAFT]. U. S. Department of Agriculture, Agricultural Research Service, USA.

Chapman, A.B. (1985). General And Quantitative Genetics. El Sevier Science publishers. B.V., New York.

El-Amin, K. M.Yousif, I.AElkhairey, M. A. and Mekki, D. M. (2011). Heritability estimates and genetic correlations for post-weaning body weight traits in Sudanese rabbits. Livestock Research for Rural Development, 23(11): .

El-Deighadi, A. (2005). Genetic evaluation for some productive traits in rabbits. Ph.D. Thesis, Fac. Agric., Moshtohor, Zagazig Univ., Banha Branch, Egypt.

El-Maghawry, A. M. (1997). Evaluation of the performance of three foreign rabbit breeds under Egyptian conditions. 2. litter size and related traits. Egyptian Journal of Rabbit Science, 7(2): 95-106. 
El-Maghawry, A. M. (1999). Genetic effects on some doe productivity in New Zealand White and Californian raised in Egypt. Egyptian Journal of Rabbit Science, 9 (2): 179-195.

El-Maghawry, A.M. Soliman, A M and Khalil, H. H. (1993). Doe milk production as affected by some genetic and environmental factors in New Zealand White and Californian rabbits under the Egyptian conditions. Egyptian Journal of Rabbit Science,3 (2): 141-150.

El-Raffa, A. M., Shebl, M. K., Kosba, M. A. and Khalil, M. H.(1997). Sire and dam transmitting abilities for litter size traits in three lines of rabbits raised in high intensive system of production. Egyptian Journal of Rabbit Science, 7 (2): 67-79.

El-Raffa, A. M. (2000). Animal Model evaluation of V line rabbits raised under Egyptian conditions. 1. Litter size traits. Journal article :Egyptian Poultry Science Journal , 20 (4): 1003-1016 ref.27.

El-Sayiad, G. H. A.(1994). A study on milk production of New Zealand White and Californian rabbits under Egyptian conditions. Egyptian Journal of Rabbit Science, 4 (1): 47-59.

Fayeye, T.R. andAyorinde, K. L. (2016). Heritability and Repeatability Estimates for Birth and Weaning Characteristics in Domestic Rabbit .International Journal of Agricultural and VeterinarySciences,2(1): 11.

Ferraz, J. B. S., Johnson, R. K. and Van Vleck, L. D. (1992). Estimation of genetic trends and genetic parameters for reproductive and growth traits of rabbits raised in subtropics with animal model. Journal of AppliedRabbitResearch, 15: 131-142.

Hanaa, A. Moustafa., El-Raffa, A., Shebl, M.K., El-Delebshany, A., NadiaA.El-Sayed (2014). Genetic Evaluation of some economic traits in a maternal line of rabbits. Egypt. Poultry Sci., 34 (I): (85-98) (1486).

Hassan, N. S. (2005 a). DF-REML Genetic Assessment of Milk Production and Efficiency of New Zealand White and Baladi Black Rabbits. Agric. Res. J.; SUez Canal University; Volume 5, 19-28.

Hassan, N. S. (2005 b). Animal model evaluation and some genetic parameters of milk production in New Zealand White and Baladi Black Rabbits using DF-REML procedure. $4^{\text {th }}$ International Conference On Rabbit Production In Hot Climates, Sharm El-Sheikh, 24-27 Feb. 2005 Egypt, 55-64.

Hassan N.S., Abdel-Ghany, A.M. and Sabri, H.M.(2015). Genetic Parameters of the Newly-Developed Egyptian APRI Rabbit Line Raised Under North-Delta Environment Using DF-REML Animal Model 1 Litter Weight traits. Veterinary Science, 1(1): 30-46. 
Hendrson, C. R. (1973). Sire evaluation and genetic trend. In: Proc. Anita and Gent. SYMP. In Honor of J. I. Lush. pp 10: 41.Amer. Soe. Anim. Sci., Champaign, II.

Iraqi, M M and Youssef, Y M K. (2006). Genetic analysis for milk production traits in New Zealand White rabbits raised in Egypt. Egyptian Journal of Rabbit Science, 16 (1):1-13.

Iraqi, M. M. (2008). Estimation of heritability and repeatability for maternal and milk production traits in New Zealand White rabbits raised in hot climate conditions. Livestock Research for Rural Development 20(8).

Khalil, M. H., Afifi, E.A., Youssef, Y.M. K. and Khadr, A. F. (1995). Heterosis, maternal and direct genetic effects for litter performance and reproductive intervals in rabbit crosses. World Rabbit Science, 3(3): 99-105.

Khalil, M. H.(1994). Locational performance of Giza White rabbits and its relation with per-weaning litter traits. Anim. Prod. , 59: 141-145.

Khalil, M.H. and Afifi, E.A. (2000). Heterosis, maternal and direct additive effects for litter performance and post-weaning growth in Gabli rabbits and their crosses with New Zealand White. $7^{\text {th }}$ World Rrabbit Con., 4-7 July 2000, Valencia Spain.

Khalil, M. H., Mehaia, M. A., Al-Homidan, A. H. and Al-Sobayil, K. A.(2004). Genetic analysis for milk yield and components and milk conversion ratio in crossing of Saudi rabbits with V-line. The $8^{\text {th }}$ World Rabbit Congress.7-10 September, Puebla, Mexico.

Khalil, M. H., Owen, J. B. and Afifi, E A (1986). A review of phenotypic and genetic parameters associated with meat production traits in rabbits.Animal Breeding Abstracts, 54 (9): 725-749.

Lukefahr, S. D., Cheek, P. R. and Patton, N. M. (1996).Heritability of milk production and 21-day litter weight and litter size in purebred and crossbred rabbits using an animal model. In: Proceedings of the $6^{\text {th }}$ World Rabbit Congress, Toulouse, France, July 1996, Volume 2: 319-323.

Lukefahr S. D. and Hamilton H. H.(1997). Heritability and repeatability estimates of maternal performance traits in purebred and crossbred does. World Rabbit Science ,5 (3): 99-105.

Moura, A.S.A.M.T., Polastre, R. and Carmelo, M.J. (1991). Genetic study of individual performance from weaning to slaughter in Selecta rabbits.J. App. Rabbit Res., 14: 228-234.

Nasr, A. S. (1994). Milk yield and some associated traits as affected by season of kindling, parity, and kindling intervals in New Zealand White doe rabbits under Egyptian conditions. Egyptian Journal of Rabbit Science, 4 (2): 149-159. 
Nofal, R. Y.; Abdel-Ghany, A. M. and Saleh K.(2002). Best linear unbiased prediction (BLUP) on some litter traits and Muscularity rate of New Zealand White rabbits under Egyptian conditions. $3^{\text {rd }}$ Science Congress On Rabbit Production in hot climates, 8-11 Oct: 127-137.

Okoro, V. M. O.; Ogundu, U. E.,Okoli, I. C.; Anyanwu, G. A.; Chikaire, J.,Raji , A. O. and Maduka, C. G. (2012). Estimation of Heritability and Repeatability for Pre-Weaning and Post Weaning Litter Weights of Unselected Domestic Rabbits in South Eastern Nigeria.International Journal of Agriculture and Forestry, 2(1):7-10.

Panella, F.; Battaglini, M.; Castellini, C.; Rosati, A. and Facchin, E. (1992). Comparison between two genetic evaluation indexes in rabbits. In: Proceedings of the. $5^{\text {th }}$ World Rabbit Congress, Oregon State Univ., Corvallis, July 1992,VolumeA, 190-197.

Ramadan, S. I. A. (2005). A study on the performance of rabbit doe for some litters, reproduction and milk production traits. M. Sc. Thesis, Faculty of Veterinary Medicine, Banha University, Egypt.

SAS. (2003). SAS Online Doc 9.13 SAS Institute Inc.,Cary, NC, USA.

Szendroe, ZS.; Nemeth-Biro, E. and Radnai, I. (1998). Development of the Pannon White breed and changes in results for production between 1988 and 1997. Journal of University of Ljubljana, Slovenia, 30:125-130.

Youssef, Y.M. K.; Omara, M. E. and Farid, A. (2008). Genetic evaluation for some litter and lactation traits in New Zealand White and Baladi Black rabbits. Egypt. Poult. Sci., 28 (IV):1203-1216.

Youssef, Y.M. K.; Iraqi, M. M. and Hassan, N. S. (2003). Heritabilities, repeatability and permanent environmental effects for maternal traits in Baladi Red and New Zealand White. Annals of Agri. Sci., Moshtohor, 41 (4): 1459-1459.

Wezyk, S. and Szwaczkowski, T. (1993). Application of animal model to the estimation of breeding value of lying hens in Poland: Present possibilities and prospects. Instytut Zootechniki Biuletynlnformacyjny, 31(1-2): 3.

Zaharaddeen, M.M. and Kabir , M. (2018). Repeatability Estimates and Principal Component Analysis of Birth and Weaning Traits in Domestic Rabbits. International Journal of Research in Agriculture and Forestry, 5, Issue 4:7-12. 


\title{
التقييم الوراثي لبعض صفات الأم وخلقه البطن وإدرار اللبن في أرانب

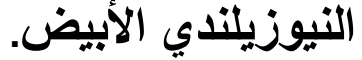

\begin{abstract}
أميرة سليمان الدغيلى إنى.

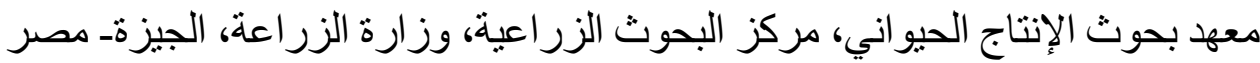

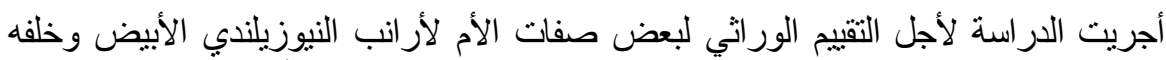

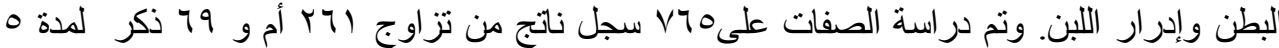

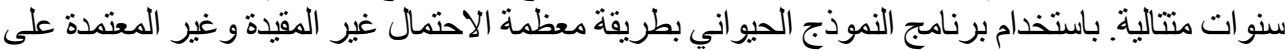

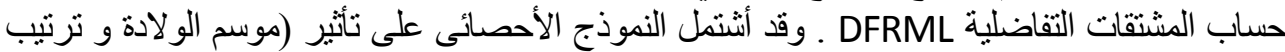

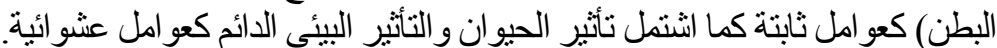

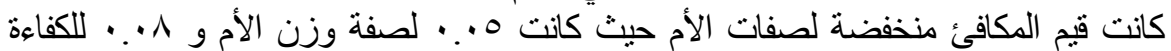

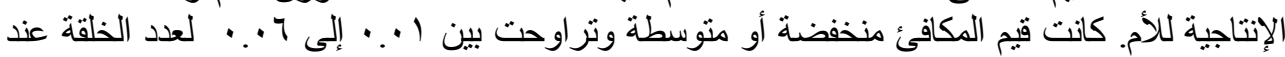

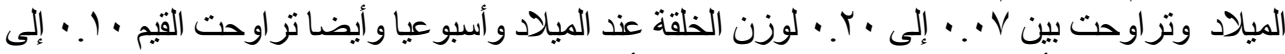

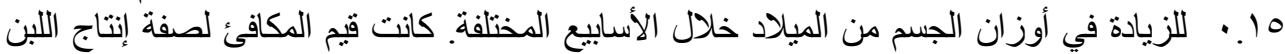

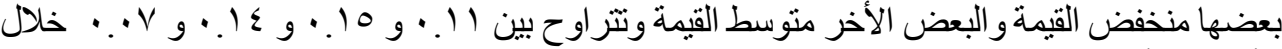
الأسبوع الأول و الثاني الثالث و الرابع على الترتيب.

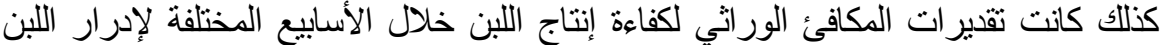

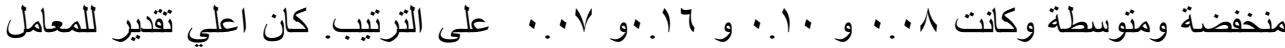

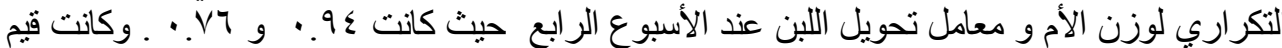

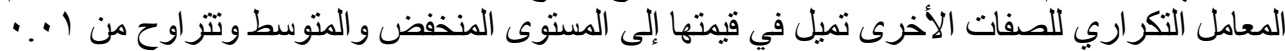

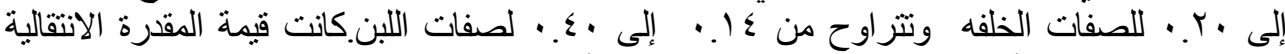

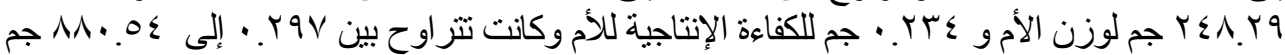

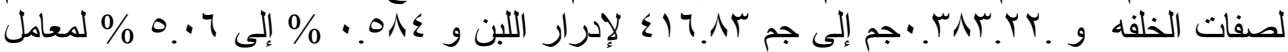

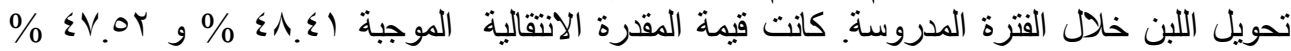

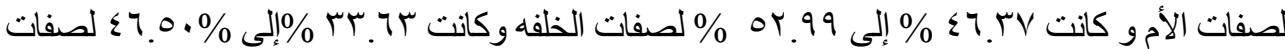
إدرار اللبن. وكاتت اعلي قيمة انتقالية لصفة عدد الخلقة عند الميلاد لذلكالك بمكن استخدامها كوسبلة لتحسين

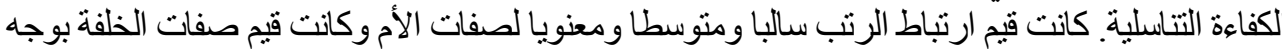

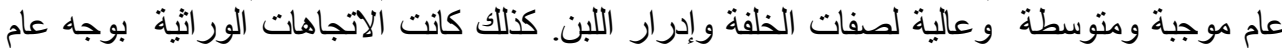

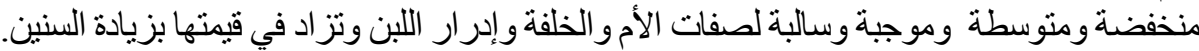

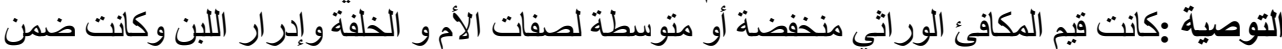

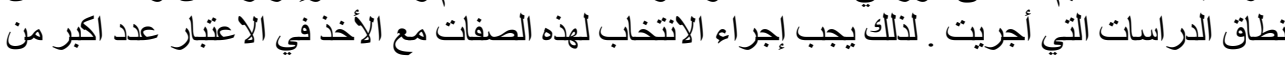

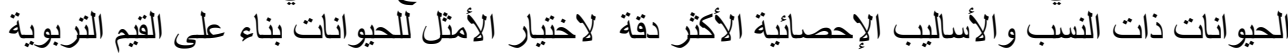

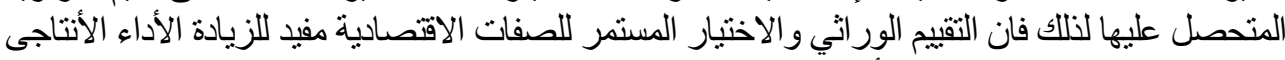
و التناسلي ونللك سيساعد منتجي الأرانب على زيادة إنتاجهم و إرباحهم. 